\title{
Fire-retardant materials
}

\author{
PUSHPA BAJAJ \\ Textile Technology Department, Indian Institute of Technology, New Delhi 110016, India
}

\begin{abstract}
Conventional materials (natural and man-made fibres, plastics, wood, paper etc.) used in everyday life are, in different degrees, liable to ignition. This fact has impelled the development of new materials which are inherently resistant to flame and heat or to modify these materials by using flame-retardant additives/treatments to meet the stringent regulations set for fire protection.

This paper gives an overview of the newly developed inherently flame-retardant fibres and engineering plastics specifically aramids, polyimides, polybenzimidazole, novoloid, polyphenylene sulphide and carbon fibres. The use of various additives and FR finishes has also been highlighted.
\end{abstract}

Keywords. Flame-retardant materials; solid phase active flame retardant; vapour phase inhabitation; aramids; carbon fibres.

\section{Introduction}

Modern technological developments have brought with them a vast increase in the kinds of hazards to which people are exposed. Hazardous environments usually have several hazardous elements. In a high-temperature environment it is possible to have noxious contaminants from a chemical fire, harmful gases are driven off from the burning substance, in combination with intense heat and smoke. These combinations make the development of a universal fire protective material difficult.

Every year about a lakh of people die and property worth a hundred crores is lost in India. To prevent such tragedies it is necessary to develop fire-resistant materials, specifically textiles and plastics used in everyday life. During the last decade, extensive work was reported in many laboratories for developing protective clothing for both industrial workers and the army. Some of the international seminars organised by the North Carolina State University in 1986, the US Consumer Product Safety Commission in 1987, and the Textile Institute, U. K. (Holme 1989) testify the importance of this field.

This review briefly describes the performance requirement of fabrics, special flame-retardant finishes, inherent fire-resistant fibres and flame-retardant plastics.

\section{Thermal protective clothing}

\subsection{Need for protection}

The thermal risks in fire situations against which the human skin has to be protected may be due to flames (convective heat), contact heat, radiant heat, sparks and drops of molten metal, and hot gases and vapours. A major cause of death in fires, however, arises from the evolution of smoke and toxic gases. In contact fires, one may say that the degree of burn injury would depend on the heat transfer to the skin. Human tissue is very sensitive to temperature. Total heat energy as low as $0.64 \mathrm{cal} / \mathrm{cm}^{2}$ 
$\left(26.8 \mathrm{~kJ} / \mathrm{m}^{2}\right)$ results in sensation of pain, and $1.2 \mathrm{cal} / \mathrm{cm}^{2}\left(50.2 \mathrm{~kJ} / \mathrm{m}^{2}\right)$ causes seconddegree burns on exposed tissues. At $45^{\circ} \mathrm{C}$, the sensation of pain is experienced, and at $72^{\circ} \mathrm{C}$ the skin is completely burnt. Protective clothing is therefore aimed at providing the time the wearer needs to react, to escape, and to avoid or minimize burns.

Thermal protective clothing should meet the following requirements:

(i) flame resistance (it must not continue to burn and be a hazard);

(ii) integrity (the garments should remain intact, that is, not shrink, melt or form brittle chars, which may break open and expose the wearer);

(iii) Insulation (garments must retard heat transfer to provide time for the wearer to take evasive action; during combustion, they must not deposit tar or other conductive liquids).

\subsection{Thermal characteristics of fibres}

Fibre or polymer combustion is a complex phenomenon that involves heating, decomposition leading to gasification (fuel generation), ignition and flame propagation. When a polymer or fibre is subjected to heat, it pyrolyzes at $T_{p}$ (figure 1 ); if volatile liquids and gases are combustible, they act as a fuel for further combustion. If, after pyrolysis, the temperature is equal to or greater than $T_{c}$, and oxygen is present, the flammable volatile liquids burn to give products such as carbon dioxide and water. In fact, when a polymer is ignited, heat from an external source raises its temperature until the material begins to degrade. The rate of this initial rise in temperature depends on the specific heat of the fibre, its thermal conductivity, and also the latent heat of fusion, vaporization or other enthalpic changes that occur during the combustion of a material.

The main sorting parameter for polymer ignitability continues to be limiting oxygen index (LOI). This determines the minimum oxygen concentration in air for polymer ignition and burning. Air normally contains $21 \%$ oxygen, so polymers with LOI $<21 \%$ are considered flammable, whereas those with LOI $>21 \%$ will not burn in normal air. In practice, materials with at least $25 \%$ LOI should have lower ignitability (table 1). Although LOI is effective in demonstrating the likely levels of ignitability of polymers, it gives only partial evidence of material behaviour towards heat or flames or both. For example, chlorofibre is very low in flammability but, with softening and contraction point at $150^{\circ} \mathrm{C}$, it would not provide adequate protection against radiant heat. Secondly, the following order of continued smouldering after burning has been reported:

polyamide fibre $<$ polyester $<$ cotton (untreated) $<$ FR cotton $<$ wool $<$ acrylic fibre $<$ modacrylic

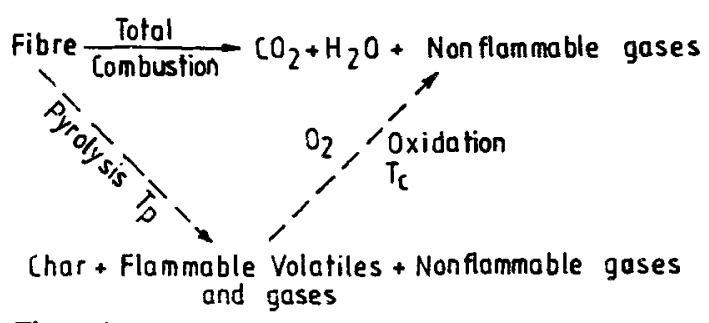

Figure 1. 
Table 1. Thermal transition temperatures of some fibres.

\begin{tabular}{|c|c|c|c|c|c|c|}
\hline Fibre & $\begin{array}{c}T_{g} /{ }^{\circ} \mathrm{C} \\
\text { (Softens) }\end{array}$ & $\begin{array}{c}T_{m} /{ }^{\circ} \mathrm{C} \\
\text { (Melts) }\end{array}$ & $\begin{array}{c}T_{p} /{ }^{\circ} \mathrm{C} \\
\text { (Pyrolysis) }\end{array}$ & $\begin{array}{c}T_{d} /{ }^{\circ} \mathrm{C} \\
\text { (Combustion) }\end{array}$ & $\begin{array}{l}\triangle \mathrm{H} \\
\mathrm{kJg}\end{array}$ & LOI \\
\hline Wool & & & 245 & 600 & 27 & 25 \\
\hline Cotton & & & 350 & 350 & 19 & $18 \cdot 4$ \\
\hline Viscose rayon & & & 350 & 420 & 19 & $18 \cdot 9$ \\
\hline Triacetate & 172 & 290 & 305 & 540 & - & $18 \cdot 4$ \\
\hline Nylon 6 & 50 & 215 & 431 & 450 & 39 & $20-21 \cdot 5$ \\
\hline Nylon 6.6 & 50 & 265 & 403 & 530 & 32 & $20-21 \cdot 5$ \\
\hline Polyester & $80-90$ & 255 & $420-447$ & 480 & 24 & $20-21$ \\
\hline Acrylic & 100 & $>220$ & 290 & $>250$ & 32 & $18 \cdot 2$ \\
\hline Polypropylene & -20 & 165 & 469 & 550 & 44 & $18 \cdot 6$ \\
\hline Modacrylic & $<80$ & $>240$ & 273 & 690 & - & $29-30$ \\
\hline PVC & $<80$ & $>180$ & $>180$ & 450 & 21 & $37-39$ \\
\hline PVDC & -17 & $180-210$ & $>220$ & 532 & 11 & 60 \\
\hline PTFE & 126 & $\geqslant 327$ & 400 & 560 & 4 & 95 \\
\hline Oxidized acrylic & & & $\geqslant 640$ & & & 55 \\
\hline Nomex & 275 & 375 & 410 & $>500$ & 30 & $28 \cdot 5-30$ \\
\hline Kevlar & 340 & 560 & $>590$ & $>550$ & - & 29 \\
\hline PBI & $>400$ & & $\geqslant 500$ & $>500$ & - & $40-42$ \\
\hline
\end{tabular}

* Limiting oxygen index

which places the fibres named almost in reverse order of desirability compared with LOI. Nevertheless, LOI remains a first reference in choosing materials (fibres/plastics) for their flammability characteristics.

In addition to the fibre characteristics and fabric finish, several garment characteristics influence thermal protection. For a given fabric thickness, the lower the density, the greater is the thermal resistance. But this is applicable to a fibre such as cotton, wool etc. which produces an insulating char on heating. Hence thicker fabrics made from cotton, wool and other non-melting fibres give good thermal protection, whereas the thicker thermoplastic-fibre fabrics produce more severe burns (Bajaj and Sengupta 1991).

\subsection{Prevention of combustion}

On the basis of the feedback mechanism (Horrocks 1986), the following four ways of stopping combustion have been suggested:

(i) Heat may be removed or cooled by treating the material with heat-absorbing products.

(ii) Increase in pyrolysis temperature to make the material heat-resistant. Glass, charcoal or semicarbon fibres and aramid fibres are extremely stable and heatresistant.

(iii) Prevent evaporation, i.e. to form nonvolatile compounds in situ, called char. This principle is used in solid-phase active flame-retardant materials based on sulphur, phosphorus or boron. Such flame-retardants form stable non-volatile esters with hydroxyl groups on substrates such as cellulose, and favour the formation of char. (iv) combustion may be prevented by eliminating the oxygen from the combustion zone and thus stopping oxidation. This principle is used in carbon dioxide and carbon 
tetrachloride fire extinguishers and is also the principle on which vapour-phase active flame-retardants operate.

Halogenated compounds operating in the gaseous phase are used in the flameproofing of synthetic fibres. Such FR compounds decompose on heating and give rise to free radicals. Such radicals can then combine with the air oxygen via complex reactions such that this combination is not suitable for the oxidation of gases generated by burning a substrate and hence combustion is inhibited.

On the above basis, flame-retardants may be classified into three major groups:

(i) Primary FR based on phosphorus and halogens, frequently combined with other products. Phosphorus by-products usually operate in the solid phase, frequently with nitrogen showing synergistic effects;

(ii) Halogenated products (chlorides, bromides), which are active in the gaseous phase, and in many cases applied together with antimony compounds in order to obtain synergistic effects;

(iii) The compounds belonging to the third category are aluminium hydrate or boron compounds, which provide endothermic reactions.

\subsection{Fire-retardant fibres}

These can be divided into two classes:

(i) inherently fire-retardant fibres, such as aramid, modacrylic, polybenzimidazole fibres, semicarbon and phenolic fibres and

(ii) chemically modified fibres and fabrics, for example, flame-retardant cotton, wool and synthetic fibres.

\section{4a Inherently fire-retardant fibres}

(a) Aramid fibre (Nomex) was developed for fighter pilots, tank crews, other military personnels, astronauts, and those working in certain specialized industrial applications. Nomex is chemically poly ( $m$-phenylene isophthalamide) fibre. Aramid fibres contain no FR chemical elements as mentioned above, but their chemical structure is such that they do not easily break down into combustible molecular fragments. Since they char on exposure to flame, such fibres provide protection from the flame. However, some aramid fabrics shrink and break open under intense heat. So, a fibre blend (Nomex III) has been recommended which is obtained by blending regular nomex with $5 \%$ Kevlar fibres.

Mitsui Toatsu Chemical Inc. of Japan, claims the development of a new kind of fire-resistant aramid fibre which is more heat-resistant than the existing aramid fibres. This new light weight but strong synthetic fibre is made from an aromatic isocyanate and an aromatic carboxylic acid (Sagar 1986). Teijin (1989) has also introduced "Super FR cloth" Xfire. It is a combination of the meta-aramid fibre 'Teijinconex' and the para-aramid fibre 'Technora'.

Polyimide fibres such as Lenzing P84 produced by the Austrian Company has excellent thermal stability. This fibre has a $T_{g}$ value of $315^{\circ} \mathrm{C}$ and a decomposition temperature of approximately $500^{\circ} \mathrm{C}$. It has LOI of $36-38 \%$. These fibres do not melt 
and can withstand constant use without any essential changes in mechanical properties at temperatures up to $260^{\circ} \mathrm{C}$ in air.

Polybenzimidazole (PBI) fibres are produced by Celanese. It shows resistance to high temperatures and chemicals with excellent textile and comfort characteristics. PBI fibre fabrics have been used in fire-fighting suits, escape suits for astronauts, and aircraft furnishing for the aerospace industry. They are claimed to give better protection against fire than aramid fibre fabrics and in addition remain flexible, maintain their integrity, and exhibit no afterglow (Jeffries 1988).

A series of subjective wearer evaluations has shown that PBI fibre exhibits comfort ratings equivalent to those of $100 \%$ cotton. In high temperature applications, PBI fibre has also been found suitable as an asbestos replacement.

Phenolic fibres (Novoloid fibres) are highly flame-retardant with a LOI of 30-35\%. Their ignition temperature is above $2500^{\circ} \mathrm{C}$. These fibres are obtained by spinning and post-curing phenol-formaldehyde resin precondensate. The fibre is soft and golden coloured, with a moisture regain of $6 \%$. When strongly heated or placed in a open flame, the phenolic fabric is slowly carbonized, with a resulting loss of strength at high temperature.

A new phenolic fibre, Philene has been developed in France. This new fibre is said to have outstanding flame resistance and has been recommended as a precursor to general purpose carbon fibres. Philene is a highly cross-linked phenolic resin (resit) and is an aromatic glassy polymer with a high carbon content of $72 \%$ by weight. The moisture regain of the fibre is $7.3 \%$ and it is said to be non-flammable and self-extinguishing with an LOI of $39 \%$. It does not show any change in tensile properties after being heated for $24 \mathrm{~h}$ at $140^{\circ} \mathrm{C}$ or for $6 \mathrm{~h}$ at $200^{\circ} \mathrm{C}$.

Chlorofibres - PVC fibres are relatively non-flammable. They do not burn nor do they emit flames or release molten incandescent drops capable of spreading fire on combustible materials. When subjected to an intense flame, PVC fibres disintegrate, but the residue can be touched, since it is not hot and there is thus no risk of burning the skin.

Polyvinylidene chloride fibres have behaviour similar to that of PVC fibres. Their flame-retardance can further be improved by the use of additives, copolymerization with monomers containing phosphorus, and coating with FR finishes. Rhovyl, chlorofibre has been used for thermal wear. Chlorofibres are claimed to be totally unaffected by water, i.e. they neither shrink nor swell in water. Nonflammable curtains made from them are in use and they have also been used in athletic clothing for its thermal comfort.

Polyphenylene sulphide fibres (PPS) are produced by melt-spinning with conventional equipment. It has an LOI value of $34-35 \%$. It does not support combustion under normal atmospheric conditions. In addition, its chemical resistance and ability to retain its physical properties under extremely adverse conditions made it valuable for protective clothing.

Polyacrylate fibres-A noncombustible polyacrylate fibre (Inidex from Courtaulds) has recently been introduced. It is a cross-linked polyacrylate fibre with an LOI of $43 \%$. When subjected to a flame, it neither burns nor melts. It emits virtually no smoke or toxic gases. FR properties therefore suggest that it should be an ideal fibre for protective clothing but there are doubts about its durability.

Semicarbon fibres produced by partial carbonization of polyacrylonitrile fibres have excellent heat resistance and heat stability, they do not burn in air, do not melt, 
and have excellent resistance to molten metal splash. After exposure to flame, there is no after-glow and fabrics remain flexible. In view of their outstanding properties, they are used in protective clothing where protection against a naked flame is required.

Pantox fibre fabrics can withstand flame temperatures in excess of $1000^{\circ} \mathrm{C}$, is resistant to most common acids and strong alkalies, and is very durable, yet it "breathes" like wool and is said to be comfortable to wear.

Semi-carbon fabrics Firotex and Asgard, based on viscose fibres, have also been developed by means of partial carbonization. However, in the $100 \%$ pure state, Firotex and Asgard fabrics are not sufficiently resistant to abrasion to allow their use in active protective clothing. Hence, blends of Firotex with aramid fibres have been recommended to minimize this problem.

A new family of advanced fibres, Pyromex carbon fibre has been introduced by Toho. This pre-oxidized fibre is claimed to show excellent performance in protective clothing for fire and security services. A list of inherently flame-resistant fibres that are commercially available is given in table 2 .

Table 2. Inherently flame-resistant fibres.

\begin{tabular}{|c|c|c|c|}
\hline Company & Fibre name & Material & Application \\
\hline \multirow[t]{4}{*}{ Du Pont } & Kevlar 49 & Aramids & Clothing for fighter pilots, tank crews \\
\hline & Kevler 29 & $\begin{array}{l}\text { Paraphenylene- } \\
\text { terephthalamide }\end{array}$ & Astranauts and for fire-fighters \\
\hline & Nomex & isophthalamide & Substitute for asbestos \\
\hline & Teflon & Fluorocarbon & \\
\hline \multirow[t]{2}{*}{ Teijin Limited } & $\begin{array}{l}\text { Exter } \\
\text { Exter A }\end{array}$ & $\begin{array}{l}\text { Polyester } \\
\text { Polyester with } \\
\text { aftertreatment }\end{array}$ & $\begin{array}{l}\text { Curtains } \\
\text { Curtains }\end{array}$ \\
\hline & $\begin{array}{l}\text { Teviron } \\
\text { Teijinconex }\end{array}$ & $\begin{array}{l}\text { Polyvinyl chloride } \\
\text { metha-linked-aromatic } \\
\text { polyamide }\end{array}$ & $\begin{array}{l}\text { Blankets, fire fighters uniform, } \\
\text { protective workwear, industrial } \\
\text { materials }\end{array}$ \\
\hline Toyobo Co. Ltd. & GH-Fibre & Polyester & $\begin{array}{l}\text { Curtains, upholstery blankets, } \\
\text { workwear converting, tickings, wadding }\end{array}$ \\
\hline Toray Industries & Unfla III & $\begin{array}{l}\text { Polyester with after- } \\
\text { treatment }\end{array}$ & Curtains \\
\hline Unitika Ltd. & Apyeil & $\begin{array}{l}\text { Metha-linked aromatic } \\
\text { polyamide }\end{array}$ & $\begin{array}{l}\text { Fire fighters uniform, workwear, } \\
\text { industrial material }\end{array}$ \\
\hline Kanebo Ltd. & Lufnen & $\begin{array}{l}\text { Modacrylic, copolymer } \\
\text { of polyvinylidene } \\
\text { chloride and acryloni- } \\
\text { trile }\end{array}$ & Carpets \\
\hline Kohjin Co. Ltd. & Cordelan & Polychlal & Curtain, Industrial filters \\
\hline $\begin{array}{l}\text { Asahi Chemical } \\
\text { industry Co. }\end{array}$ & $\begin{array}{l}\text { Cashmilon A83 } \\
\text { Cashmilon A85 } \\
\text { Nonbur N80 } \\
\text { Nonbur N90 }\end{array}$ & $\begin{array}{l}\text { Acrylic } \\
\text { Acrylic } \\
\text { Acrylic } \\
\text { Acrylic }\end{array}$ & $\begin{array}{l}\text { Carpets } \\
\text { Blankets } \\
\text { Blankets } \\
\text { Curtains }\end{array}$ \\
\hline $\begin{array}{l}\text { Mitsubishi Rayon } \\
\text { Co. Ltd. }\end{array}$ & $\begin{array}{l}\text { Valzer } \\
\text { Super Valzer }\end{array}$ & $\begin{array}{l}\text { Acrylic } \\
\text { Acrylic }\end{array}$ & $\begin{array}{l}\text { Carpets. blankets } \\
\text { Curtains }\end{array}$ \\
\hline Kuraray Co. Ltd. & Nannex & Polyester & Waddings, tickings \\
\hline
\end{tabular}


Table 2. (Continued)

\begin{tabular}{|c|c|c|c|}
\hline Company & Fibre name & Material & Application \\
\hline Rhone-RPT & $\begin{array}{l}\text { Kermel } 234 \\
235 \text { AGF }\end{array}$ & AGF polyamide & Fire-fighters suit \\
\hline Poulene France & Rhovyl & Chlorofibres & Thermal wear, upholstery, curtains \\
\hline Heochst-Celanese & PBI & Polybenzimidazole & $\begin{array}{l}\text { Nonflammable protective suites, brake } \\
\text { parachuts, leather lines }\end{array}$ \\
\hline $\begin{array}{l}\text { Lenzing AG } \\
\text { (Austria) }\end{array}$ & $\begin{array}{l}\text { P84 fibre } \\
\text { Lenzing PTFE } \\
\text { Lenzing viscose }\end{array}$ & Polyimide & $\begin{array}{l}\text { Asbestos replacement, } \\
\text { Protective garments, } \\
\text { Protective gloves, garments }\end{array}$ \\
\hline Avtex & Durvil F-40 & FR viscose & \\
\hline Courtaulds & INIDEX & Acrylic & Blankets, flame resistant interlinings \\
\hline R. K. Textiles & PAN-OX & Oxidized acrylic fibre & Protective clothing \\
\hline $\begin{array}{l}\text { Universal } \\
\text { Carbon fibres }\end{array}$ & PANOTEX & - & $\begin{array}{l}\text { As a substitute for asbestos, protective } \\
\text { gloves, interlinings. }\end{array}$ \\
\hline $\begin{array}{l}\text { Toho Rayon } \\
\text { Co. Ltd. }\end{array}$ & Pyromex & $\begin{array}{l}\text { Pre-oxidized fibre } \\
\text { (carbon fibre) }\end{array}$ & \\
\hline $\begin{array}{l}\text { Isover Saint } \\
\text { Gobain, France }\end{array}$ & $\begin{array}{l}\text { Philene } 244 \\
\text { Philene } 206\end{array}$ & Phenolic fibre & FR felts \\
\hline Eastman & Kodel & Polyester & \\
\hline $\begin{array}{l}\text { Monsanto } \\
\text { Chemical Co. USA }\end{array}$ & SEF & Modacrylic & FR clothing \\
\hline $\begin{array}{l}\text { Albany Inter- } \\
\text { national mono- } \\
\text { filaments } \\
\text { Plant N.Y. } \\
\text { U.S.A. }\end{array}$ & $\begin{array}{l}\text { Halar \& } \\
\text { Tefzel }\end{array}$ & Fluorocarbon & \\
\hline $\begin{array}{l}\text { Albany \& Philips } \\
\text { Fibres Corp. }\end{array}$ & $\begin{array}{l}\text { Ryton } \\
\text { PEEK }\end{array}$ & $\begin{array}{l}\text { Sulphur } \\
\text { Polyether ether ketone }\end{array}$ & \\
\hline
\end{tabular}

Source: Textile World Aug. 1986, p. 39 and High performance fibres (1988) 8. (9), p13.

Modacrylic fibres: This generic class was developed specifically to improve the behaviour towards flames of acrylic fibres, by way of copolymerization with chlorine-containing monomers, specially vinylidene chloride. Main examples are Teklan (Courtaulds) and Monsanto SEF. The latter is used in USA for tents, awnings and upholstery, but possible workwear uses must be restricted to those in which radiant heat is not encountered. However, the ignitability of modacrylic fibres is rather low.

\section{Flame-retardant plastics}

The increased use of plastics in present-day life has resulted in a growing awareness of flammability problems associated with these materials. Since polyolefins, and specially polypropylene, and polyvinyl chloride are involved in a wide range of applications, the developments in the area of flame-retardants suitable for 
polypropylene, and use of various fillers to produce flame retardant low smoke PVC cables, have become an important area of research.

\subsection{Polypropylene}

Polypropylene burns with a hot smoke free flame without leaving a char residue. Since polypropylene has a high self-ignition temperature $\left(570^{\circ} \mathrm{C}\right)$ and a rapid decomposition rate as compared to wood and other cellulosic materials, flame retardation of polypropylene is rather difficult. Moreover, in these thermoplastics polymers, as burning is accompanied by dripping and flowing of the flaming polymer, a flame-retardant should therefore not only cause extinction of the burning polymer but also prevent the flaming drip which is more injurious.

Antimony/halogen containing flame-retardant additives have been used for obtaining flame-retardarit polypropylene. Among antimony compounds, antimony trioxide is favoured. Other antimony compounds which are equally effective, e.g. antimony trisulphide, triphenyl stibine, sodium antimonite, can also be used. Halogen compounds which can decompose to give hydrogen halide are used in conjunction with antimony trioxide but the effectiveness of an antimony-halogen system depends upon the type and nature of the halogen compound.

Bromine compounds were found to be more effective than chlorine compounds. In the hexabromocyclododecane- $\mathrm{Sb}_{2} \mathrm{O}_{3}$ system, only $1.5 \%$ bromine is required besides $1 \% \mathrm{Sb}_{2} \mathrm{O}_{3}$ to achieve optimal flame retardancy. Among aliphatic alicyclic, and aromatic halogen compounds, the choice is aliphatic and alicyclic, because a halogen attached to an aromatic ring is too stable. Various examples support this statement. $13.7 \% \mathrm{Br}$ and $5 \% \mathrm{Sb}_{2} \mathrm{O}_{3}$ are required for bis(2, 4, 6-tribromophenoxy) propane, and for decabromodiphenyl ether $17 \cdot 8 \% \mathrm{Br}$ and $7 \cdot 2 \% \mathrm{Sb}_{2} \mathrm{O}_{3}$ are needed to impart flame retardancy, whereas aliphatic or alicyclic halogen compounds are required at low additive levels for imparting flame-retardancy, e.g. hexabromocyclododecane $(1.5 \%$ $\mathrm{Br}$ and $1 \% \mathrm{Sb}_{2} \mathrm{O}_{3}$ ) and the dibromo adduct of maleic anhydride and cyclopentadiene $\left(3.05 \% \mathrm{Br}\right.$ and $\left.2.9 \% \mathrm{Sb}_{2} \mathrm{O}_{3}\right)$. Some patents also reveal that the use of both types of halogen compounds besides $\mathrm{Sb}_{2} \mathrm{O}_{3}$ gives better results (Jha et al 1984).

Combinations of different halogen $\left(\mathrm{Cl}\right.$ and $\mathrm{Br}$ ) compounds with $\mathrm{Sb}_{2} \mathrm{O}_{3}$ in one flame-retardant formulation were found to give better results compared to the cases where chlorine or bromine compounds were used separately along with $\mathrm{Sb}_{2} \mathrm{O}_{3}$.

In our laboratories, triphenyl stibenedibromide and its derivatives with tribromo-, trichloro- and pentachlorophenols have been used as flame-retardant additives for polypropylene. The maximum LOI of $31.5 \%$ against 18.2 for unfilled polypropylene was obtained in a sample containing $10 \mathrm{phr}$ of triphenyl stibine dibromide. However, V-O rating in UL-94 test was observed in 20 phr flame retardants filled PP samples, while V-2 rating was obtained even at 5 phr FR level. Analysis of FR polypropylene residue obtained in isothermal treatment at $450^{\circ} \mathrm{C}$ for $30 \mathrm{~min}$ in air confirmed the role of these flame retardants in vapour phase (Jha et al 1986; Bajaj et al 1987).

\subsection{Other element-based flame retardants}

Antimony/halogen systems pose some problems of corrosion and toxic fumes during processing. This has led to the development of nontoxic flame-retardant systems based 
on magnesium and aluminium. However, these flame-retardants are required at high concentrations (40-60\%) for imparting a good degree of flame retardancy. In a polypropylene formulation containing $40 \% \mathrm{Mg}(\mathrm{OH})_{2}$, the addition of $3 \%$ quinacridene was found to improve flame retardance. Improvement in flame retardance was also noticed in other cases where ammonium polyphosphate, $\mathrm{Fe}_{3} \mathrm{O}_{4}$ or $\mathrm{MgO}$ is added to PP besides $\mathrm{Mg}(\mathrm{OH})_{2}$.

Among aluminum compounds, hydrated alumina is mostly used. The flameretardant effectiveness seems to be due to the endothermic release of water. However, higher loadings of $\mathrm{Mg}(\mathrm{OH})_{2}$ or $\mathrm{Al}_{2} \mathrm{O}_{3} \cdot 2 \mathrm{H}_{2} \mathrm{O}$ result in poor mechanical properties and processability. To overcome these problems, surface treatments of the fillers are recommended.

The organotin compounds have also been used as FR fillers. They were found to work both by flame-poisoning and by char formation. In flame poisoning it is hydrogen halide, whereas in condensed phase it is $\mathrm{SnO}_{2}$-containing compound which prevents access of air and cools the flame by fast heat removal.

\subsection{Flame-retardant and low smoke (FRLS) PVC cables}

Outlets for flame-retardant cables include all types of potentially hazardous areas such as power stations, high rise buildings, oil rigs, mines, tunnels, chemical plants etc. PVC is used as a major sheath material because of its inherent flame-retardant characteristics $(\mathrm{LOI}=45 \%$ ), chemical resistance and good mechanical strength. However, the plasticizers like dicotyl phthalate used in PVC processing adversely affect its flame-retardant property. Moreover, PVC on burning produces toxic gases and heavy smoke.

The prime objective of flame-retardant additives for PVC is therefore to produce FRLS cables. For achieving this, the following options are available according to the literature reviewed by Bajaj (1988):

(i) To add sufficient antimony oxide, as a synergist which reacts with halogen of PVC to form antimony trihalide via antimony oxyhalide. The more the $\mathrm{SbCl}_{3}$ in the gas phase, the higher is the LOI of the polymer. It has been further shown that volatile metal halides with relatively weak metal-halogen bonds are extremely effective flame retardants.

(ii) Molybdenum oxide along with antimony oxide works as a synergist. Zinc molybdate, calcium zinc molybdate have also been used in PVC formulation to obtain charring to self-extinguishing type cables.

(iii) Antimony zirconate when used at $10 \mathrm{phr}$ level produces self extinguishing PVC.

(iv) Application of sulphide, boride, nitride of aluminum, chromium, copper, iron, molybdenum, tin and titanium in PVC formulation showed increased char formation and reduction in smoke.

(v) Low melting sulphate glasses and ceramics based on potassium sulphate-sodium sulphate-zinc sulphate ternary system are effective fire and smoke retarder additives for PVC. Addition of 10 phr of sulphate glass in tin stabilized PVC compound resulted in $54 \%$ reduction in smoke while at $40 \mathrm{phr}$ the smoke reduction was by $83 \%$. A combination of ternary glass and molybdenum oxide seem to be a potential fire and smoke retarder at low phr level. For example, $10 \mathrm{phr}$ of the ternary glass and $5 \mathrm{phr}$ of $\mathrm{MoO}_{3}$ gave a smoke reduction by $78 \%$ (Kroenke 1986 ). 
(vi) By substituting combustible plasticiser, DOP with chlorinated paraffin and trialkyl or alkylaryl phosphate plasticizers helps in retaining the FR properties of the PVC cables.

\section{Conclusions}

The data presented support the hypothesis that phosphorus-based FR are solid-phaseactive and influence the thermal behaviour of the substrate while antimony/halogen systems are vapour-phase-active and change the flame chemistry. A wide range of inherently flame-resistant fibres are available today in the world market but their selection for a specific hazardous environment, say contact heat, radiant heat, flames or hot gases would depend on their thermal characteristics.

\section{References}

Anon 1988 High Perf. Fibres 814

Bajaj P, Jha N K, Maurya P L and Misra A C 1987 J. Appl. Polym. Sci. 341785

Bajaj P 1988 Proc. Seminar on Power cables and accessories, CPRI, Bangalore, 12-13 Dec.

Bajaj P and Sengupta A K 1991 Textile Progress (A quarterly review journal published by The Textile Institute, Manchester) Vol. 20

Holme I 1989 Textile Horizons, June p 52

Holme I 1989 Textile Horizons July p 54

Horrocks A R 1983 J. Soc. Dyers Colorist 99191

Horrocks A R 1986 Rev. Prog. Coloration 1662

Jha N K, Misra A C and Bajaj P 1984 JMS-Rev. Macromol. Chem. Phys. C24 69

Jha N K, Bajaj P, Misra A C and Maurya P L 1986 J. Appl. Polym. Sci. 324393

Jeffries R 1988 Textile Asia 2272

Kroenke W J 1986 J. Mater. Sci. 211123

Sagar A J G 1986 Textiles 152

Teijin Ltd 1989 Textile Horizons, June p 37 